\title{
Effects of Climate Changes on Water Resources: A Case of Mindu Dam in Morogoro Municipality, Tanzania
}

\author{
Simon R Melchioly \\ University of Dar es Salaam, Department of Geosciences P. O. Box 35052 Dar es Salaam, \\ Tanzania. \\ Email: melchioly@gmail.com; melchioly@udsm.ac.tz \\ Received 15 Oct 2020, Revised 13 Aug 2021, Accepted 15 Aug 2021, Published Aug 2021
}

DOI: https://dx.doi.org/10.4314/tjs.v47i3.33

\begin{abstract}
This paper presents the findings of the research conducted in Morogoro Municipality, central Tanzania. The main objective of the research was to assess the climate change impacts on water resources, taking the Mindu Dam as the case study. The study methodology involved collection, processing and analysis of both primary and secondary data. Data collection involved acquisition of Dam water level data, climate data, and Landsat 8 satellite imagery. Research findings showed that the maximum air temperature increased at a rate of $0.045 \%$ on a span of 30 years, while rainfall has been decreasing with time. Also there has been a decreasing trend of water level in the Mindu Dam such that the coefficient of determination $\left(\mathrm{R}^{2}\right)$ appeared to be very small $(0.95 \%)$. The area also has witnessed an increasing trend in wind speed $\left(\mathrm{R}^{2}=63.4 \%\right)$ for the period 2014 to 2019. The results showed coefficient of determination $\left(\mathrm{R}^{2}\right)$ for water production/supply of only $1.58 \%$, while for water demand the coefficient of determination was $\mathrm{R}^{2}=77.13 \%$. Findings on the changes in surface area covered by the Mindu Dam reservoir due to climate change impacts showed that for the period of 19 years, the Mindu Dam reservoir surface area decreased by $0.57 \%$.
\end{abstract}

Keywords: Climate change, water resources, Mindu Dam, land use change.

\section{Introduction}

Water is a critical input into any country's economy, including Tanzania. In Tanzania, the water sector plays important roles as it underpins the performance of the agricultural sector which employs $80 \%$ of the workforce (URT 2019). The agricultural sector accounts for $43 \%$ of the country's GDP and $54 \%$ foreign exchange earnings (World Bank 2021). Water is also an important resource for the development of industrial production; for example, mining, a key sector in Tanzania's Development Vision 2025, depends on reliable water supply for power generation since hydropower for instance, provides $55 \%$ of the country's power generation (ECA 2019). The Mindu catchment is located in Wami-Ruvu basin in the south-west of Morogoro municipality. Stresses on water resources have been increasing due to several factors such as rapid population growth, improper land use, deforestation, and climate change (Vera et al. 2010). Evidences show that Ngerengere River used to be perennial in the late 1990s, but today it gets dry during the dry season, and this phenomenon is not only directly linked to decreased rainfall, but also increase in temperature (Fetch 2019). Tanzania's population has grown rapidly in the last 50 years, going from 10 million in early 1960 s to approximately 45 million in 2012 (NBS 2012). It is also projected that the population for the year 2022 might be around 65 million, at which point the country's per capita water resources 
will fall below the current $1,600 \mathrm{~m}^{3}$ per person (UNESA 2019). Although the presented population increase is for the entire country, it reflects the situation at municipal levels as well. Therefore, even in Morogoro municipality, the population has increased tremendously from 316,866 in 2012 Census to approximately 600,000 in 2020 , resulting in exponentially increase in water consumption (UNESA 2019). On the other hand, since early 1990s, the climate variability has resulted in unpredictable rainfall distribution which has led to droughts in some parts of Morogoro region and the entire country at large (TMA 2019). Water demands for Morogoro Municipality as in March 2017 were estimated to be $47,066 \mathrm{~m}^{3} /$ day, whereas installed water production was $34,000 \mathrm{~m}^{3} /$ day (MORUWASA 2018).

Around the globe, especially in west part of the United States, there are reports of water supply shortages due to droughts. The amount of water available in those areas is already limited, and demands will continue to rise as the population grows. Many areas in the west US have experienced less rain over the past 50 years, as well as increases in the severity and length of droughts (US EPA 2017). At global scale, the available evidence from measurements and global climatic models such as General Circulation Models (GCMs), Atmosphere-Ocean General Circulation Models (AOGCMs) and Hadley Centre Climate Models (HadCM) among others, indicates that the world is experiencing warming for the past few decades (IPCC 2019).

At a local scale, some studies on climate change impacts on water resources have been conducted in Tanzania, and one of the comprehensive studies on climate change in Tanzania was by Mwandosya et al. (1998), which was undertaken during the period 1994 to 1996. The study involved modelling of rainfall and temperature increases, assessing changes in river water flows, impacts on crop production, and sea level rise (Fetch 2019). According to Mwandosya et al. (1998), the General Circulation Model (GCM) was used in his study utilizing the data for the years 19511980 as the base line. Some of the findings from the study were such that; temperature would increase between $3.6{ }^{\circ} \mathrm{C}$ to $3.8^{\circ} \mathrm{C}$ in the south and western parts of Tanzania, and between $2.7{ }^{\circ} \mathrm{C}$ to $3.1^{\circ} \mathrm{C}$ in the south-eastern, eastern and northern parts of the country. Also, the rainfall would increase by $5-45 \%$ in northern and south eastern areas of the country, with the highest increases occurring close to Mount Kilimanjaro. On the other hand, rainfall would decrease by $5-15 \%$ in central, western, south western, southern and eastern parts of Tanzania by the year 2075 . It is anticipated that there will be a doubling of baseline concentrations of greenhouse gases by 2075 (Mwandosya et al. 1998). However, the General Circulation Model (GCM) approach in modelling climate effects on water resources is much suitable for regional studies. It is due to this fact that statistical approach has been chosen in order to improve the accuracy of the results.

This paper is based on studies undertaken in south-west of Morogoro Municipality between 2013 and 2015 which looked into the climate change impacts on water resources management and community livelihoods. However, the data used in this paper, the context, and conclusions made are specifically for Mindu Dam in Morogoro Municipality. The main objective of this study was to find out whether the continued water level decrease in Mindu Dam for the past 20 years is due to climate change/variability. Specifically, the research intended to assess various interventions that will lead into stabilization of the water level in the Mindu Dam, such as water supply and demand assessment, climatic conditions assessment and land cover/land use assessments.

\section{Materials and Methods \\ Study area location}

The Mindu Dam is located in the Ngerengere River about $6 \mathrm{~km}$ south-west of Morogoro Town on the Tanzania-Zambia highway, and it gets water from Mindu catchment which lies to 
the north-west of the Uluguru Mountains (Figure 1 and Figure 2(a)). The major tributaries which bring water to the Ngerengere River include Mzinga, Mgeta, Mlali and Lukuleni. The reservoir is located at an elevation of $500 \mathrm{~m}$ above mean sea level, between 9240000 and 9242000 Northings and between 346000 and 348000 Eastings. The Mindu catchment has approximately a surface area of $303 \mathrm{~km}^{2}$ (Ngonyani and Nkotagu 2007).

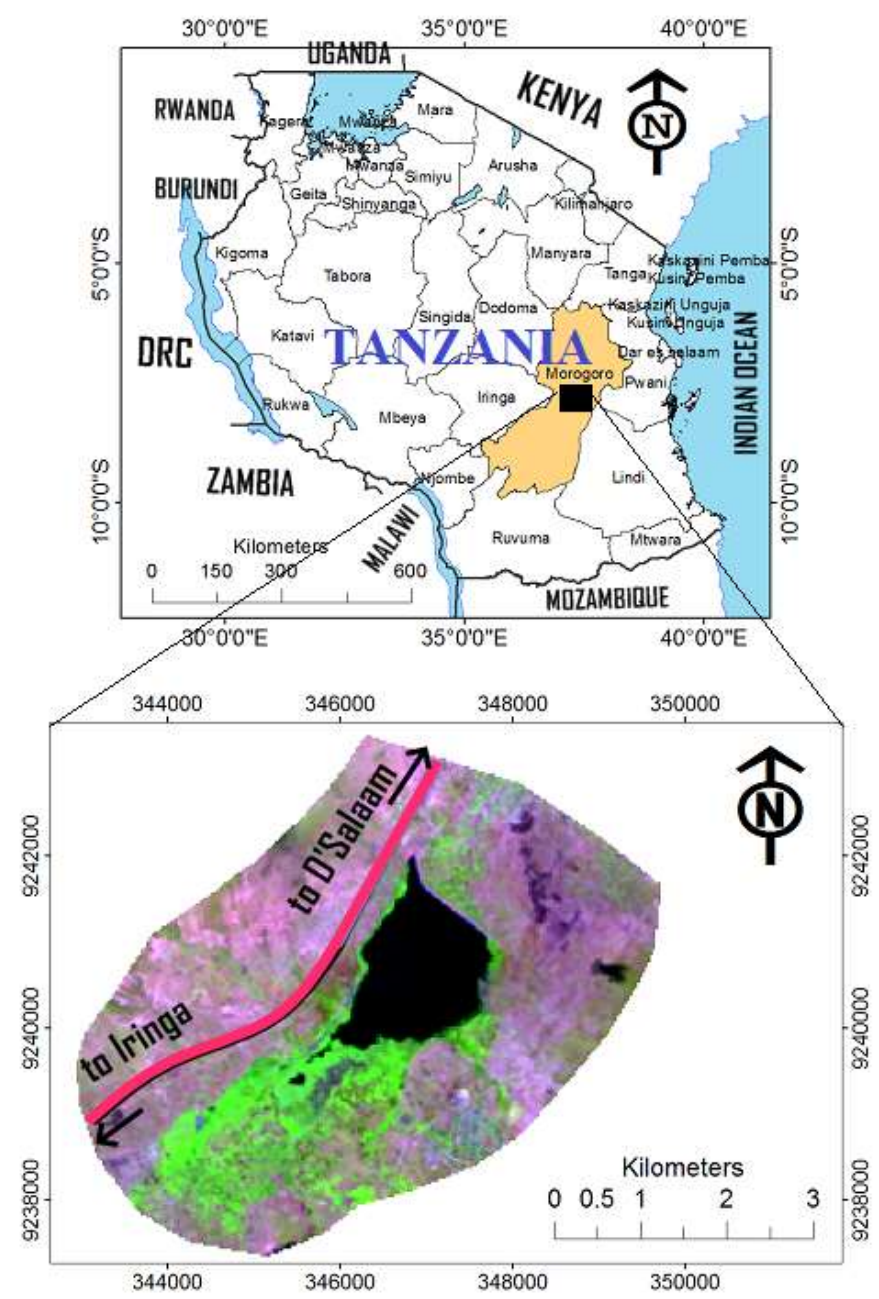

Figure 1: Map showing the study area, Mindu Catchment, and Mindu Dam locations. This image was created by the author through digitization and extraction from the satellite imagery.

\section{Methods}

\section{Primary data collection}

The primary data collected were the Mindu Dam water levels during the wet season and dry season of the 2018/2019 hydrologic year. These data were correlated with the secondary data collected by Morogoro Urban Water and Sanitation Authority (MORUWASA) for the past years. 


\section{Secondary data collection}

Secondary data collection involved acquiring and studying satellite imagery and digital elevation model (DEM) in order to analyze the land use/land cover changes of the area within the Mindu Dam catchment. The digital elevation model used had spatial resolution of 30 meters, while the satellite imagery had spatial resolution of 15 meters. Other secondary data collected included rainfall, temperature, humidity, evaporation, and previous water level data. The climatic data were collected from Tanzania Meteorological Agency (TMA), while previous dam water levels were collected from MORUWASA.

\section{Data analysis}

Software package used in processing satellite imagery included ArcGIS 10.4 (ESRI 2018) and ERDAS IMAGINE 2018 (HEXAGON 2018). Unsupervised classification algorisms were used in carrying out the land use/cover classifications. Digital satellite imagery data from Landsat 8 OLI for the years 1999, 2008 and 2018 were acquired from USGS (2020) website. Time series data analysis was accomplished such that the hydrometeorological data were analyzed using the common statistical software packages which included Grapher version 8.3 (Golden Software Inc. 2016) and MS-Office.

\section{Results and Discussion}

Climate change and status of water resources in Morogoro Municipality

A large amount of water that enters the Mindu catchment and finally into the dam comes from the Uluguru Mountains. Most of the river tributaries feeding the Ngerengere River come from the Uluguru Mountains. Ngerengere River flows in SW-NE into the Mindu Dam, while the tributaries flow in the SE-NW directions (Figure 2(a)). Therefore, the Uluguru Mountains are found in south, southwest and south-east of the Mindu catchment and in the north-east of the Mindu Dam there are Kasanga hills where there are about three major river tributaries flowing into the Mindu
Dam. The watershed delineation map presented in Figure 2(b) was generated from the digital elevation model (DEM) of the area (Figure 2(a)). Topographical data from the DEM indicate that there is elevation difference between the Mindu Dam and the Uluguru Mountains such that the dam surface is at 502 meters above mean seal level, while the peak of Uluguru Mountains are at an elevation of 1866 meters from mean sea level.

The results in Figure 3(a) show that, while the maximum air temperatures have been on a rise though at a moderate rate, the rainfalls have been decreasing with time but at times becoming intermittent with unpredictable patterns. The temperatures appear to be increasing at a rate of $0.045 \%$ on a span of 30 years which implies that over that period, the area has witnessed a temperature increase of $1.35{ }^{\circ} \mathrm{C}$. The results also show that the frequency of higher rainfall events were observed between the years 1997 and 2000, but since then the region has witnessed reduced frequencies in higher rainfall events. The general rainfall patterns have changed in such a way that unpredictable heavy rainfall could occur in a short time causing damages to property and loss of lives while not benefiting the society due to being unexpected. Such a scenario has just happened in the year 2020 whereby very heavy rainfall down poured in the region during the months of the year where people usually use the time to prepare farms. So, though it was heavy rain, but it was not much useful for agricultural activities as it caught the farmers' off-guard. Such a phenomenon highlights the exact nature of the impacts of climate change. The declining trends in the amounts of rainfall for the period 1997 to 2019 (Figure 3(a)) for Morogoro and the surrounding regions appear to support the local perceptions that for the past 20 years, they have witnessed intermittent and decreased river flows and water levels in most rivers and in reservoirs as it has been observed in past and present days.

On the other hand, the declining of water level in the Mindu Dam for the period 1997 to 
2019 (Figure 4(b)) appear to support again the beliefs of the local community for the two decades they have observed declining water availability for domestic and industrial usewith reduced water accessibility also make people to walk long distances to fetch water especially women. The results in Figure 4(b) show a decreasing trend of water level in the Mindu Dam though at a very slow rate as the coefficient of determination $\left(\mathrm{R}^{2}\right)$ appear to be very small $(0.95 \%)$. However small the water level decreasing rate will be, it is important for water supply authorities to take precaution measures such as looking to new sources of water to support the Mindu Dam. The results presented in Figure 4(a) show the relationship between rainfall and water level situation in the Mindu Dam for the period 1997 to 2019. It can be observed that water level fluctuations in the Dam corresponded to the rainfall events such that every heavy rainfall event is accompanied by increased amplitude in water level in the dam. It is therefore quite obvious that prolonged drought has led to the decrease in water level in the dam and hence affecting water supply services. The declining trend in the Mindu Dam water production for the period 2013 to 2019 (Figure 5 (b)) for Morogoro Municipality shows the real impacts of climate change on water supply for domestic, agricultural and industrial uses. For the past years, there have been observed amplified occurrences of drought, in which in 2017 the Mindu Dam was closed due to not having water completely (Figure 3(b)). The US EPA (2017) report presented similar findings on water level decrease in rivers in west USA due to impacts of climate change.

Also drought has caused drying of vulnerable vegetation, particularly grasses and trees and this has accelerated siltation of the dam because of increased surface runoff. The results presented in Figure 5 (a) show that for the period from 2013 to 2017 , the water supply production was meeting the demands, but after 2017 the demands surpassed production and hence led to have water supply deficit. Currently, it can be observed that Mindu Dam water supply production stands at around $750,000 \mathrm{~m}^{3} / \mathrm{month}$ while demands are approximately at $1,800,000 \mathrm{~m}^{3} /$ month; this makes the water supply deficit to be $140 \%$. The region has observed a continued rise in surface temperatures over the years (Mwandosya et al. 1998). The increased trend in surface air temperature for the period 1997 to 2019 (Figure 3(a)) for Morogoro Municipality indicates the evidence of a warmer climate over time; there are arguments within the society that they have seen tremendous increase in wind speeds above normal and that this has resulted in destruction of properties such as houses and crops. The increasing trend in wind speed for the period 2014 to 2019 (Figure 4(c)) appears to support the arguments of the local community. Sunshine has also increased in recent years compared to the past three decades. This has led to increased evaporation and evapotranspiration, and this is evidenced on the decreasing trend of relative humidity for the period 2014 to 2019 (Figure 4(d)); and another element that describes the effects of climate change at community level is the frequent outbreaks of diseases such as malaria and cholera in the region. The above mentioned local indicators of climate variability are similar to those reported by various scholars (Kangalawe 2012, Steven and Mkonda 2015, Paavola 2004 ) in which they described effects of climate change on natural resources and human health. It can be summarized that social characteristics of the society and biophysical environment are the major determinants of the local community's climate change perceptions. 

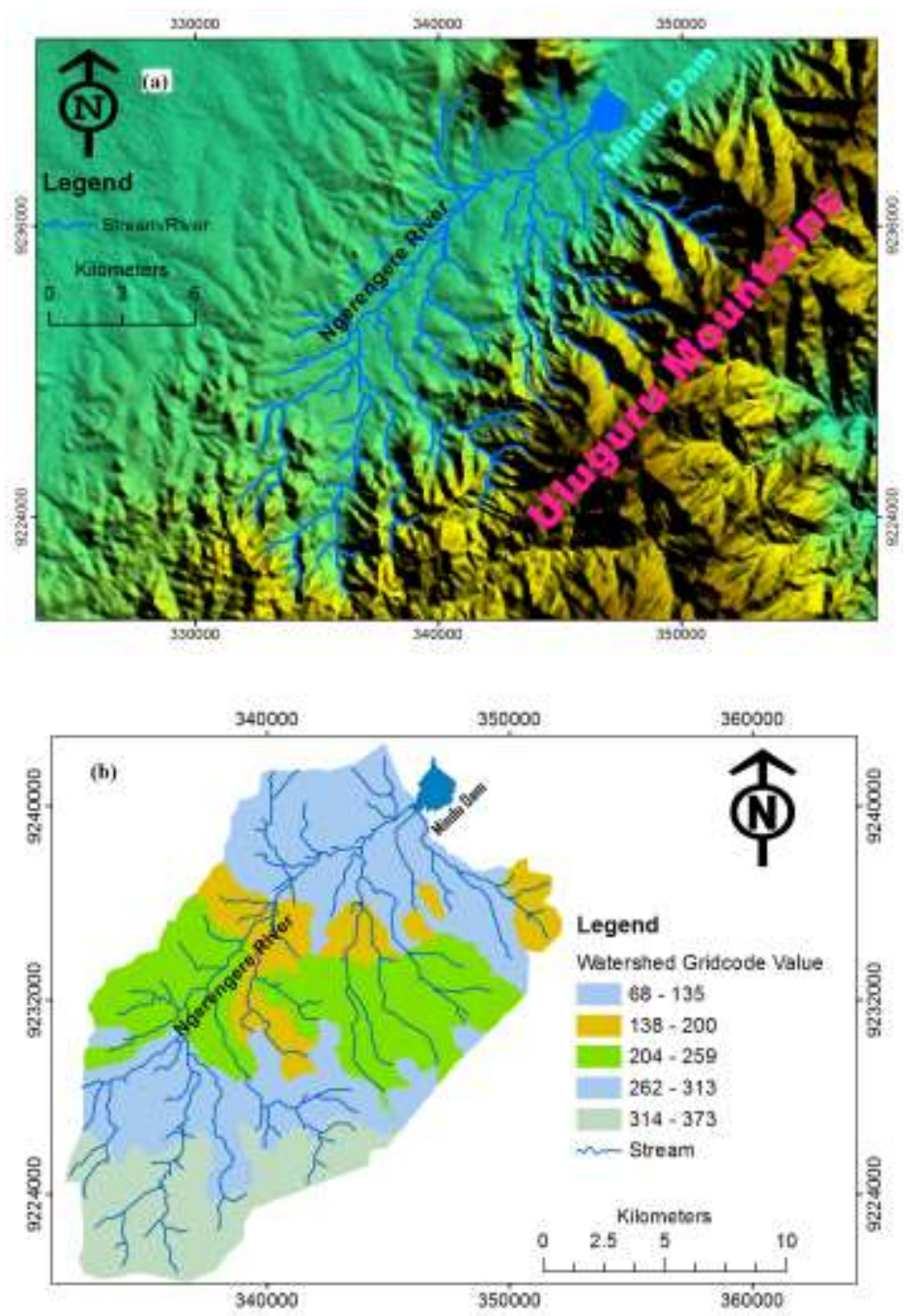

Figure 2: Map showing (a) Digital Elevation Model (DEM) and (b) Watershed Delineation for the Mindu Catchment in Morogoro Municipality. 

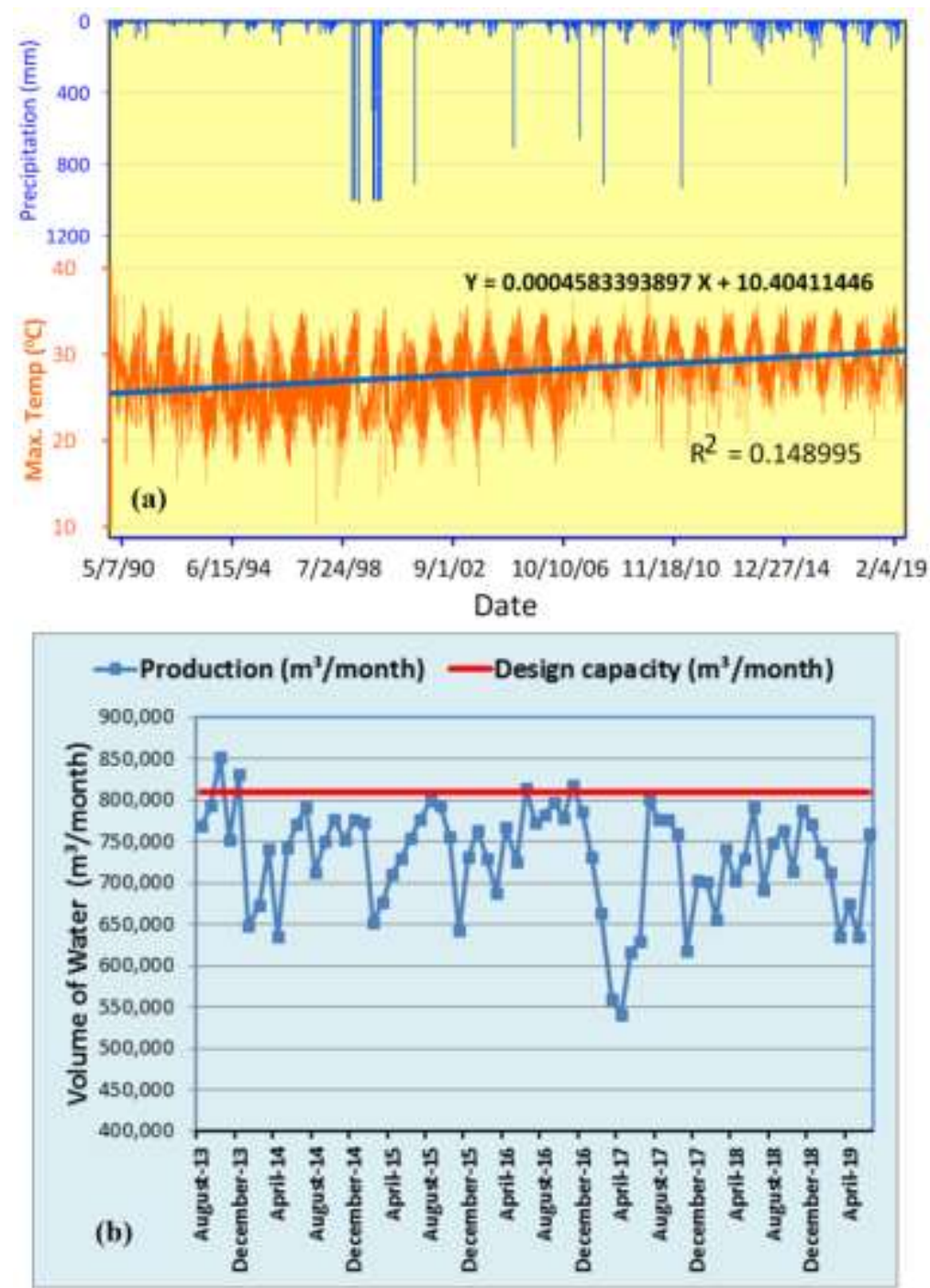

Figure 3: Variations between: (a) Maximum air temperature versus rainfall for the period 1990 to 2019, (b) Mindu Dam Water Supply (Production) and water demand in Morogoro Municipality for the period 2013 to 2019. 

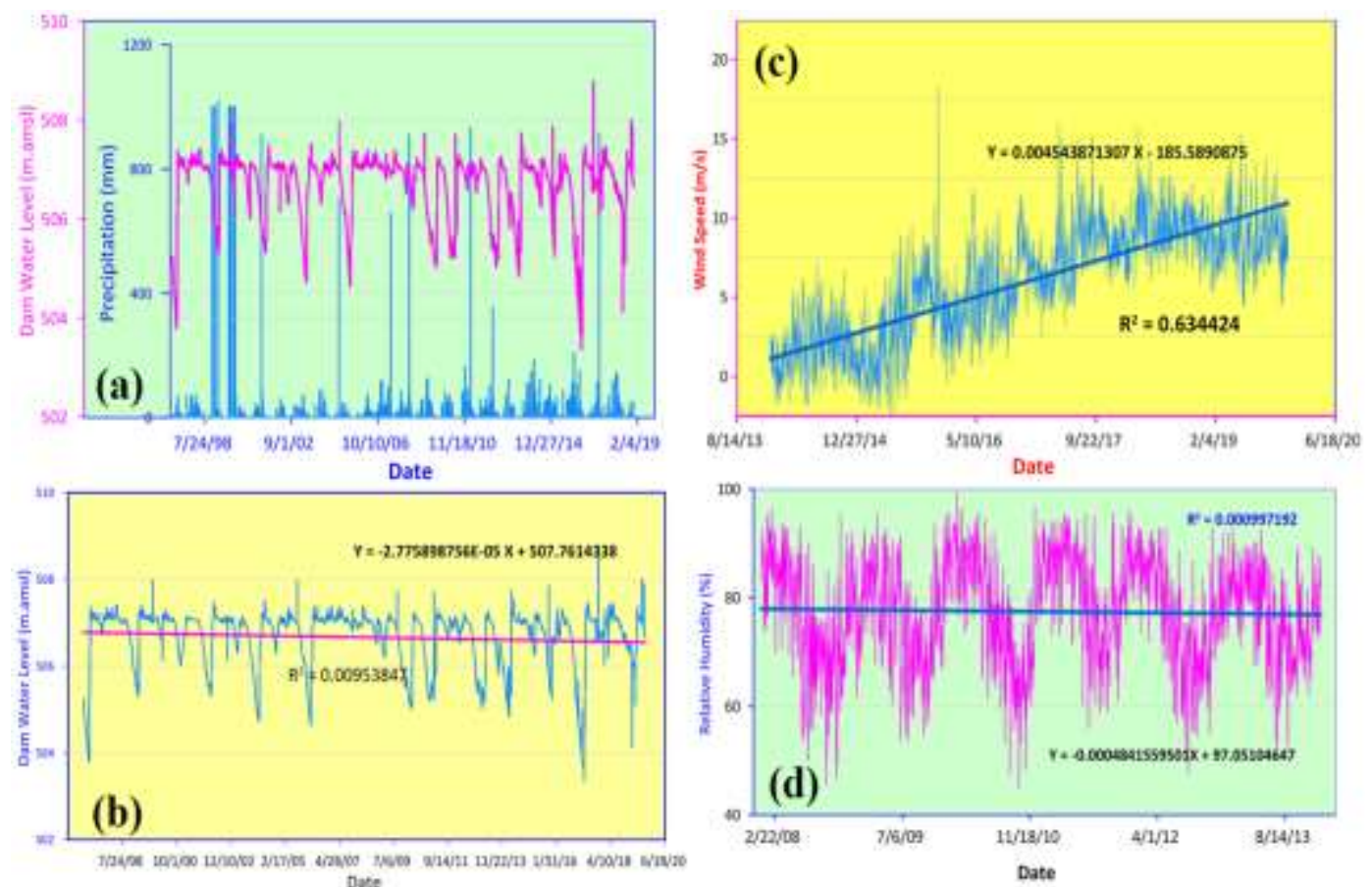

Figure 4: (a) Variations between Mindu Dam water level versus rainfall for the period 1997 to 2019, (b) The trend of water level in Mindu Dam for the period 1997 to 2019, (c) The trend of wind speed in Mindu catchment for the period 2013 to 2019, (d) The trend of relative humidity for the period 2008 to 2013.

Trending climate change impacts on water supply and demand in Morogoro Municipality

The results presented in Figure 5(a) show that water production and supply for the Morogoro Municipality is no longer meeting the demands since October 2017. The results show that while production is decreasing with time, the water demands are on the contrary increasing, and this could be attributed by several factors which may include rapid population growth, increased industrial activities and irrigation requirements. Water demand results (Figure 5(a)) indicate a three stage scenario, in which the first stage is observed to have approximately water demands of about $1,200,000 \mathrm{~m}^{3} /$ month for the period up to April 2016. The second stage with water demand reaching $1,400,000 \mathrm{~m}^{3} /$ month goes from April 2016 to October 2017. The third stage in water demands is the maximum with the currently available data, and it amounts to $1,800,000 \mathrm{~m}^{3} / \mathrm{month}$. The water supply production data on the contrary have been fluctuating for the entire period and although there is an increasing trend (Figure 5(b), but the level of production is less as compared to the demands. The trend analysis results for water supply/production show that the increase rate is quite small as compared to the water demands. The coefficient of determination $\left(\mathrm{R}^{2}\right)$ for water supply is only $1.58 \%$, while for water demands the coefficient of determination $\left(\mathrm{R}^{2}\right)$ is $77.13 \%$ (Figure 18). These results indicate that there are very small to negligible correlations among the two datasets. The increasing rates of water demands are quite higher than the corresponding rates for water production and supply. 


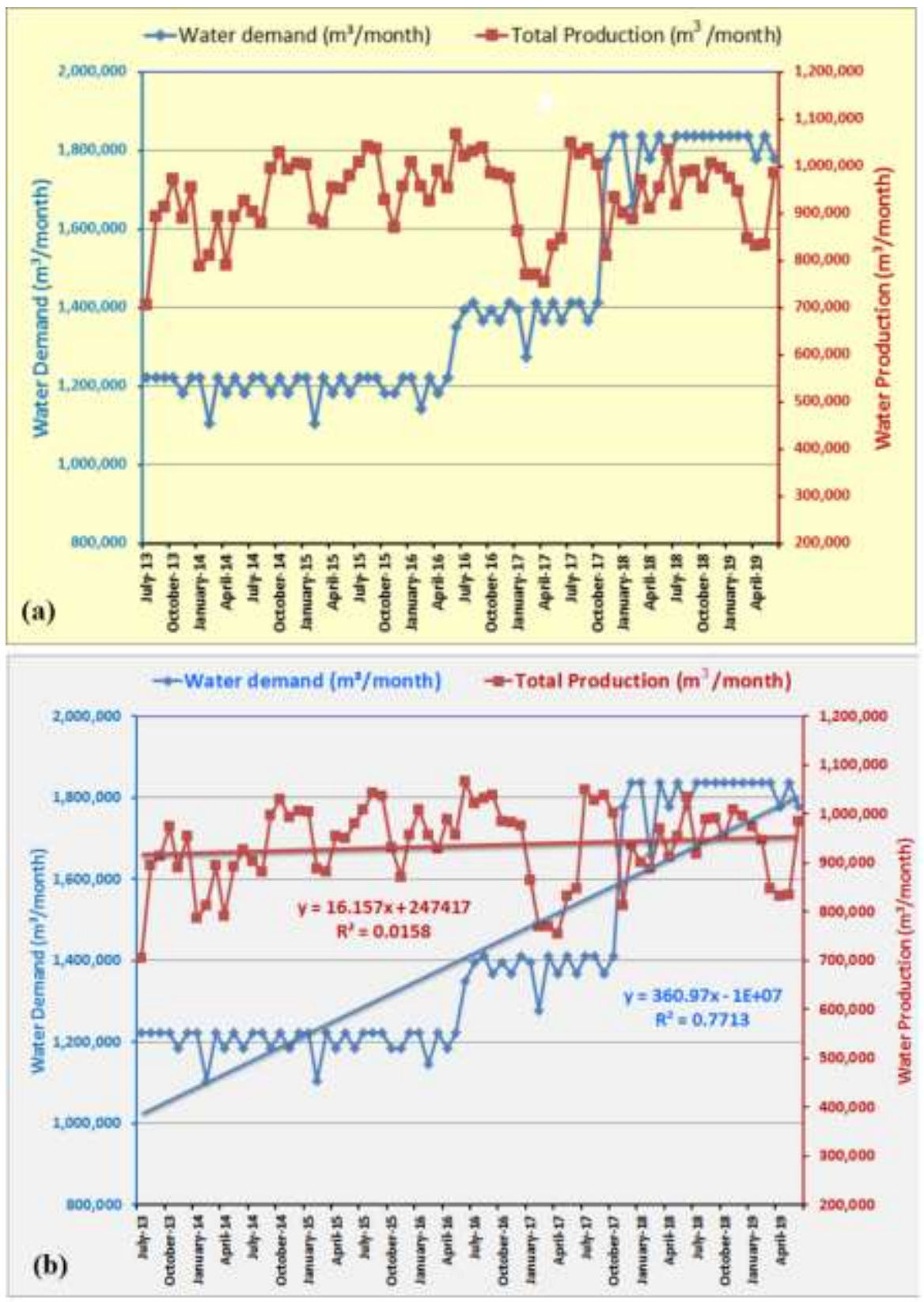

Figure 5: a) Variations between total water supply (total production) and demand in Morogoro Municipality, (b) The general trend between total water supply (total production) and demand in Morogoro Municipality.

Since the study area is located at the foot of Uluguru Mountains between the Udzungwa highlands and the coastal terraces, it is anticipated to experience a mixture of climate change impacts. The region will be affected by both drought and flooding which will have 
adverse effects on food production, land cover, water availability, human settlements and human health. Already the region has faced devastating flooding in 2019 to 2020 leaving scores of people dead and destruction of properties (URT 2019). The recent flooding is evidence that already the region is experiencing climate variability which exemplifies the possible impacts of climate change in the future. However, the significance and challenges of present climate variability and predicted future climate changes can only be appreciated by first looking at the sources of vulnerability in the region. Together with the impacts of climate change that affect water resources in the only large reservoir for the Morogoro Municipality, water shortages problem could be solved by constructing larger storage tanks as well as increasing efforts in exploration and usage of groundwater resources.

There are some efforts being made by the government to try resolving the water supply shortages in Morogoro Municipality. Some of the efforts include construction of a new water intake at Mambogo in Ngerengere River, installation of new 3 pumps at Mafiga treatment plant, rehabilitation and upgrading of Mafiga water treatment plant. These efforts were a result of the Millenium Challenge Corporation (MCC) financing. Other initiatives in improving the water supply capacity for the MORUWASA were the extension of existing DN700 pipeline to Mindu Dam, and installation of additional DN600 pipeline from Mindu Dam to Mafiga treatment plant. Also, there are future plans of increasing the storage capacity of the Mindu Dam by raising the existing dam embankment from the current level of 507 masl by 2.5 metres to 509 masl. Extension of the dam embankment will increase the dam capacity to enable expansion of Mafiga treatment plant as planned. However, there is a problem of reduction of the source of water which is feeding the Mindu Dam, and that is the Mindu catchment. The reported reduction in surface area of the catchment is due to encroachment by settlements and agricultural activities. Hence, it is vital to restore all the catchment areas which are very crucial in feeding the dam, but also proper management mechanisms are necessary to enhance benefits of enlarging the dam reservoir.

\section{Climate change impacts on operations and safety of surface water supply dams}

The dam production results presented in Figure 3(b) indicate that for the October and December 2013, the produced water was beyond its design capacity. Based on the available reports, this was due to increasing demands as a result of rehabilitation that was being done on the gravity sources infrastructures, so the water production from gravity sources was reduced, and hence forced MORUWASA management to increase production from the Mindu Dam slightly beyond its design capacity which is 810,000 $\mathrm{m}^{3} / \mathrm{month}$. The Mindu Dam also was operated beyond its design capacity in June and November 2016, and the reasons given by the water supply authority are to mitigate water shortages due to drought since there was no sufficient rainfall, hence the gravity sources could not produce to their designed capacities.

\section{Climate change, land use/cover changes and the status of water resources in Mindu Dam catchment}

Land use/cover changes affect water resources in several ways depending on the particular change or use. Reduction in forest cover will affect the water resources negatively as there will be an increase in surface runoff which might cause siltation of dam reservoirs. Also, reduction in forest cover will allow the direct sunlight to reach the bare ground, and this will lead to increased evaporation and thereby affecting soil infiltration characteristics. In case of an increase in forest cover (afforestation), then this phenomenon will tend to preserve the soil moisture and thereby having positive impacts on water resources. On the other hand, increased agricultural activities will always affect water 
resources negatively as it might lead to clearing of forest cover of which as we have discussed this will lead to increased surface runoff, reduction in soil moisture, and changes in soil structure (soil degradation) due to direct exposure to sunlight. Agricultural activities within or close to the Mindu Dam catchment may also cause pollution to the water resources due to usage of fertilizers and other pesticides. Therefore, in putting everything together, it becomes evident that climate change, water resource conditions, and land use/cover changes influence one another. It is obvious that climate changes and land use/cover changes have impacts on water resources.
Table 1 shows the land use/cover classification results, in which four (4) classes of land use/cover of Earth surface features were chosen for major land use/cover classes of the Mindu catchment. The number of pixels used to calculate the total area for each class is presented together with the pixel size of the satellite data imagery being 30 meters. The total area for each feature class was determined by multiplying the area of each pixel by the total number of ground pixels. Percentage for each feature class was established by taking the ratio of individual feature class area to the total area of all the feature classes.

Table 1: Land use and land cover classification results for Mindu catchment

\begin{tabular}{lllll}
\hline Year & Count [Pixels] & Class & Area $\left(\mathrm{m}^{2}\right)$ & \% Area \\
\hline 1999 & 2493 & Water body & 2244271.68 & 8.682781 \\
& 12260 & Vegetation & 11036811.39 & 42.69992 \\
& 6926 & Cultivated land & 6234988.23 & 24.12232 \\
& 7033 & Bare land/soil & 6331312.767 & 24.49498 \\
2008 & 2412 & Water body & 2171353.106 & 8.400669 \\
& 8460 & Vegetation & 7615939.998 & 29.46503 \\
& 12735 & Cultivated land & 11464420.32 & 44.35428 \\
2018 & 5105 & Bare land & 4595670.649 & 17.78002 \\
& 9322 & Water body & 2097726.353 & 8.115519 \\
& 35646 & Vegetation & 7151714.07 & 27.66799 \\
& 45355 & Cultivated land & 11077790.57 & 42.85689 \\
& 24535 & Bare soil & 5521102.345 & 21.35961 \\
\hline
\end{tabular}

In order to assess the impacts of climate changes on water resources in relation to land use/cover changes, digital satellite imagery for the study area were acquired and analyzed to determine the change detection in land use/cover changes. The digital satellite imagery used was for the years 1999, 2008, and 2018. The research results for the land use/cover change assessments for the Mindu catchment are presented in Figure 6(a), Figure 6(b), and Figure 6(c). The land use/cover assessment results show that the Mindu Dam reservoir has been decreasing with time, and this is directly attributed to the impacts of climate change. It can be observed that in the year 1999, the Mindu Dam reservoir was covering $8.68 \%$ of the Mindu catchment (Figure 6(a), but in the year 2008 the dam reservoir was covering only $8.4 \%$ of the Mindu catchment. In the year 2018, the Mindu Dam reservoir surface area continued to decrease and it is observed that in this particular year the reservoir only occupied $8.11 \%$ of the Mindu catchment. It therefore an obvious fact that for the period of 19 years, the Mindu Dam reservoir surface area has decreased for about $0.57 \%$ of the catchment. The observed decrease in surface area of the Mindu Dam water reservoir is equivalent to 150 hectares. 
Tanz. J. Sci. Vol. 47(3) 2021

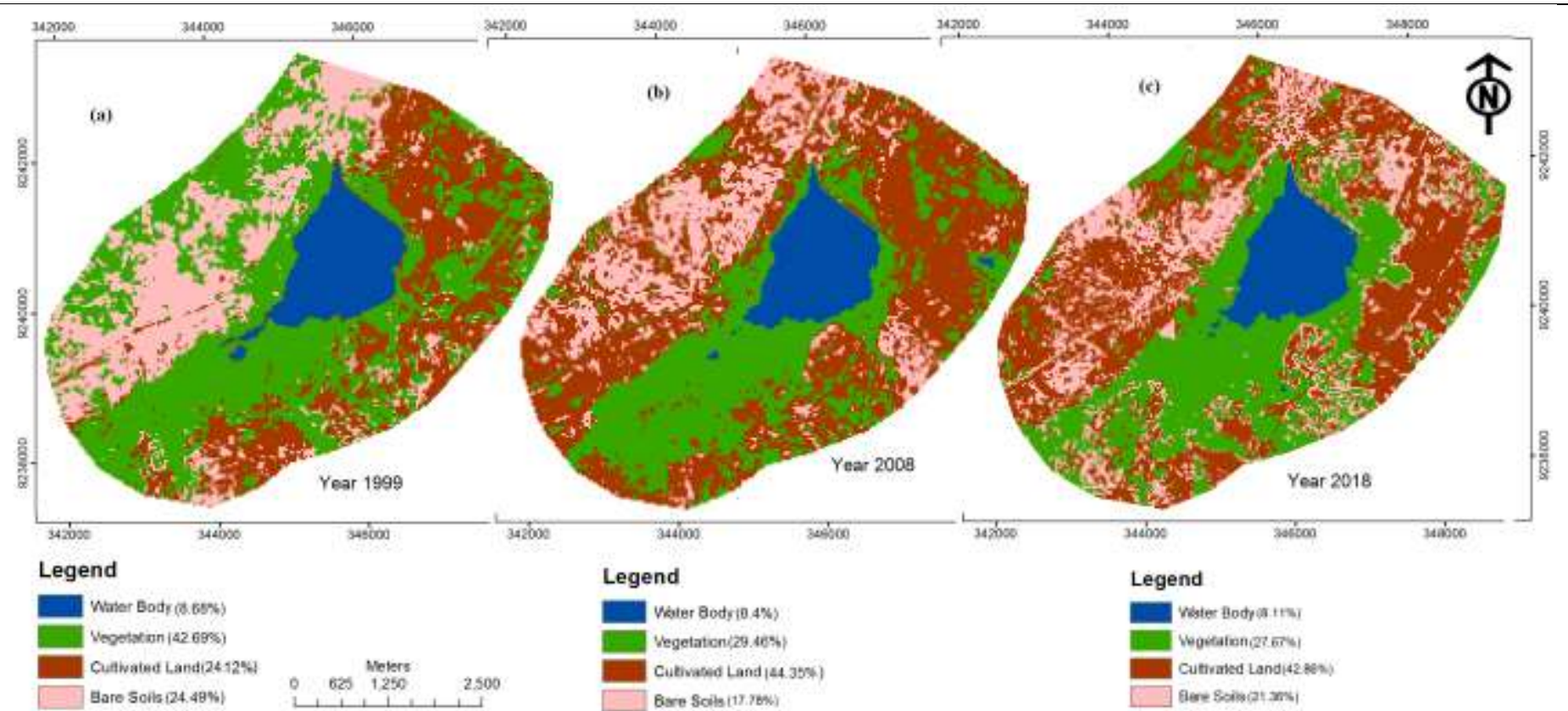

Figure 6: Mindu Dam Catchment land use/cover classification results: (a) for the year 1999, (b) for the year 2008, (c) for the year 2018. 
Green vegetation cover in 1999 covered $42.69 \%$ of the Mindu catchment (Figure 6(a), while in 2008 (Figure 6(b) it occupied only $29.46 \%$. The decreasing trend of the Mindu catchment area covered by green vegetation continued as in the year 2018 (Figure 6(c) it shows that only $27.67 \%$ of the catchment was covered by green vegetation. Although the date and time when the satellite imagery was taken could have some impacts on the vegetation cover, but it is obvious that climate changes have adverse impacts on vegetation cover. Reduction in rainfall will tend to affect plants including grass growth and hence affect green vegetation cover. Cultivated land in 1999 covered $24.12 \%$ of the Mindu catchment (Figure 6(a), while in 2008 (Figure 6(b) it occupied only $44.35 \%$. For the case of cultivated land, the trend has been increasing as the area of the Mindu catchment covered by cultivated land in the year 2018 (Figure 6(c) was $42.86 \%$ of the catchment. These results show that there have been increases in agricultural activities in the areas within the Mindu catchment. Kirimi et al. (2018) reported the dynamics of land use and land cover changes in the Kilombero basin which have resulted in reduced forest cover land. The increase in drought becomes a forcing factor leading people to look for wet areas that could sustain their crops growth. In recent years, there has been also an increase in vegetable agriculture in wet lands, which has contributed to destruction of protected wet lands, and this is also the case for the Mindu catchment.

The land use/cover classification results for Mindu catchment also show that bare soils in 1999 covered $24.49 \%$ of the Mindu catchment (Figure 6(a), while in 2008 (Figure 6(b) it occupied only $17.78 \%$. For the case of the year 2018 (Figure 6(c), the results show that the Mindu catchment area covered by bare soils increased up to $21.36 \%$ of the total catchment area. The increase in surface area for the bare soils could be attributed to drought, but also human activities such as agricultural activities. As it has been observed that there has been a tremendous increase in agricultural activities, so it is quite obvious that much of the area will be cleared for various purposes related to agriculture.

\section{Conclusion}

Mindu Dam is the only large water supply source for Morogoro Municipality, however, in recent years, it has been found out that the declining of water level in the dam for the period 2007 to 2019 has been attributed by variability in rainfall patterns and intensity for the region. The declining trends in Mindu Dam water production for the period 2013 to 2019 for Morogoro Municipality show the real impacts of climate change on water supply for domestic, agricultural and industrial uses. In recent years there have been observed amplified occurrences of drought in which in 2017 the Mindu Dam was closed due to not having water completely.

The decrease in rainfall amounts reduces the water that enters the Mindu Dam reservoir during dry seasons and hence affecting the water level in the dam, and this has direct impacts on the sustainable community livelihood in terms of water supply and food security. The land use/cover assessment findings from this research showed that the Mindu Dam reservoir surface area have been decreasing with time, and this is directly attributed by the impacts of climate changes together with other factors such as deforestation and siltation. It is due to this fact that proactive land use management policies should be emphasized so as reduce deforestation and other natural resources degradation. The environmental management awareness campaigns should go hand-in-hand with enhancing climate change local adaptation measures among communities, water sector stakeholders, and the general public.

Disclosure statement: No potential conflict of interest related to this work.

\section{Funding}

This research was supported by the University of Dar es Salaam through the "UDSM 
Competitive Research Grants Programme" project no. CoNAS-GY19057.

\section{References}

ECA Working Group 2019 Economics of Climate Adaptation: Shaping climate-resilient development. Economics of Climate Adaptation Working group based on a partnership between the Global Environment Facility. Annual Report.

Environmental Systems Research Institute (ESRI) 2018 ArcGIS. Release 10.4. Redlands, CA. https://www.esri.com/enus/arcgis/products/arcgis-pro/overview

Fetch S 2019 How Climate Change Impacts Our Water.

https://news.climate.columbia.edu/2019/09/23 /climate-change-impacts-water/

Golden Software Inc. Grapher version 8.3 https://www.goldensoftware.com/products/gra pher

Hexagon Geodpatial Inc. 2018 ERDAS Imagine. Release 2018. Madison, AL. https://download.hexagongeospatial.com/do wnloads/imagine/erdas-imagine-2018

IPCC 2019 An IPCC Special Report on climate change, desertification, land degradation, sustainable land management, food security, and greenhouse gas fluxes in terrestrial ecosystems.

https://www.ipcc.ch/site/assets/uploads/2019/ 11/SRCCL-Full-Report-Compiled-191128.pdf

Kangalawe RYM 2012 Food security and health in the southern highlands of Tanzania: A multidisciplinary approach to evaluate the impact of climate change and other stress factors. Afr. J. Environ. Sci. Technol. 6(1): 5066.

MORUWASA 2018 Morogoro Urban Water Supply and Sewerage Authority (MORUWASA). Summary Reports (2017, 2018).

Mwandosya MJ, Nyenzi BS and Luhanga ML 1998 The Assessment of Vulnerability and Adaptation to Climate Change Impacts in Tanzania. Centre for Energy, Environment,
Science and Technology (CEEST), Dar es Salaam, Tanzania.

NBS 2012 National Bureau of Statistics (NBS): 2012 Census Preliminary Report.

Ngonyani CJ and Nkotagu HH 2007 Study of nutrient pollutants and their impacts on the water quality of the Mindu reservoir at Morogoro Municipality. Tanz. J. Eng. Technol. 1(3): 138-148.

Paavola J 2004 Livelihoods, vulnerability and adaptation to climate change in the Morogoro region, Tanzania, CSERGE Working Paper EDM, No. 04-12, University of East Anglia, The Centre for Social and Economic Research on the Global Environment (CSERGE), Norwich.

Steven S and Mkonda M Y 2015 Climate Variability Impacts, Diseases and Human Health: The Case of Morogoro Municipality, Tanzania. Arch. Bus. Res. 3(5) 78-90.

TMA (Tanzania Meteorological Agency) 2019 Climate Assessment Annual Report.

UNESA 2019 World Population Prospects: the 2019 Revision Population Database http://esa.un.org/unpp/

URT 2019 Water Utilities Performance Report for 2017/2018. Energy and Water Utilities Regulatory Authority (EWURA), United Republic of Tanzania.

US EPA 2017 Climate Impacts on Water Resources. https://19january2017snapshot.epa.gov/climat e-impacts/climate-impacts-waterresources. $\mathrm{html}$

USGS 2020 Landsat 8 OLI satellite imagery download. Retrieved from Earth Explorer: https://earthexplorer.usgs.gov/LC08_L2SP_1 67065_2020101020201016_02_T1/

Vera C, Parey S, Polovina J, Poveda G, Seguin B, Barange M, Dube O P, Goddard L, Griggs D, Kobysheva N, Odada E, and Trenberth K 2010 Needs Assessment for Climate Information on Decadal Timescales and Longer. Proc. Env. Sci 1: 275-286.

World Bank 2021 Economic status for Tanzania. https://www.worldbank.org/en/country/tanzan ia/overview 